\title{
The Strategy Analysis of Teaching Innovation of Tourism Management Major in University
}

\author{
Lei Chen \\ Business School \\ Linyi University \\ Linyi, China \\ e-mail:chenlei@lyu.edu.cn
}

\begin{abstract}
A relatively mature system of personal tourism management education has been built in China, but there is still a big gap in market demand. This paper lists the problems in the tourism management education in Chinese universities, including a poorly designed professional curriculum, obsolete pedagogy, with greater emphasis on theory not on practice in teaching content, simplistic teaching evaluation and the lack of doubleposition teachers. Based on the above problems, this paper proposes specific, innovative measures to promote the improvement of tourism management teaching in Chinese university focusing on adjusting curriculum, reforming pedagogy, strengthening practice teaching, cultivating students scientific research ability, increasing teachers' experience and rebuilding teaching evaluation.
\end{abstract}

Keywords-University; Tourism management; Teaching innovation; Strategy

\section{INTRODUCTION}

Tourism became one of the fastest growing industries in China supported by rapid economic development and a relatively stable society. This has led to an increased demand from the market for people with high-level tourism skills, and to meet this need, tourism courses at universities have become popular. Many universities expanded enrollment, but the skill shortage in the tourism industry has not been improved, even with more and more tourism major graduates of. One reason is that many tourism major students resign after realising the huge contrast between their career ideal and real work. A second reason is that the tourism industry believes that graduates have not been trained adequately and are incompetent in tourism management. This phenomenon shows that tourism management teaching did not achieve the training goal, or it lags behind the tourism development needs. Therefore it is vital for universities to reform tourism management teaching.

\section{Problems EXISTING IN THE TOURISM MANAGEMENT EDUCATION OF CHINESE UNIVERSITIES}

Tourism education and research was born with the tourism industry after the Reform and Opening up in 1978[1], when it was clear that the industry itself lacked experience, with no

This research was financially supported by the Humanities and Social Sciences Youth Project of the Ministry of Education of China (Grant NO. 10YJC790024). theoretical preparation and no professional skills. The teaching system imitated the teaching materials and basic theory of developed countries; the teachers were hired from other semirelated majors such as geography and history. With the rapid development of the tourism industry, universities expanded enrollment to meet the market demand, but the quality of graduates did not improve with the increase of the number. Investigating the reasons for this disparity, the author discovered the following problems in tourism management teaching.

\section{A. Curriculum disparity from the industry reality}

- At present a big problem at the Chinese Tourism University is the arbitrariness in the teaching plans [2]. Tourism management majors in China lack the standard management of a professional teaching plan, universities plan only according to their own understanding, with research into industry reality and requirements. This situation of "set this course because of somebody" will inevitably create disparity between universities, with no cohesive curriculum or standards of coursework or teaching

- Curriculum setting is not effective. Firstly, there are few course teaching natural sciences, humanities, and social science, so there are fewer options for students to choose cross major courses. Secondly, there is obviously insufficient time to teach content for the basic courses, such as management, economics, statistics, accounting, economic law, psychology and management information systems. Thirdly, there are also few courses to develop learning skills for students. One reason for students' lack of creativity is the lack of necessary guidance in teaching methodology in education content; therefore, courses for teaching scientific thinking and research should be established in the beginning.

\section{B. Obsolete pedagogy}

The tourism management major reflects the disconnect between modern teaching methods or pedagogy, and reality, and results in students being unable to apply any skills gained from the courses.. The traditional teaching mode for tourism management is usually "take classroom, teachers, and knowledge as center", and this mode hinders the teaching of 
learning skills, which is more important than teaching knowledge. By neglecting the students' participation, teachers limit the students' potential at the same time. The traditional "injecting" teaching method is to make "cramming" compulsory indoctrination, organize the students' independent learning activities and guide the learning method. This obsolete pedagogy ignores or dismisses any initiatives of the students and reduces student motivation. It can only teach students to imitate and memorise, but suppress the development of students' learning initiative and creativity.

\section{Emphasis on theory not practice}

The first tourism management courses focused on theory, with little emphasis on practice, and this focus impacted negatively on current tourism management training. Students are unable to apply their theoretical learning to the reality of the industry, and this can be seen not only in the tourism industry but also across the board. The focus becomes the classroom not the industry. At present, most universities are still carrying out a centralized fixed mode of practice teaching, not reflecting the level differences in students. In addition, the content is too simple and does not go deeper, so that students cannot master the skills that the jobs really need. Many universities lack suitable practical opportunities. The lack of practical skills and the lack of opportunity to build skills through practical application in real world situations has been the weak link of tourism education for years. Many universities don't establish a practice base due because of funding difficulties or the need is underemphasized, leading to a disconnect from the real environment [3]. In some cases cooperation between the university and enterprise is very volatile, creating instability in course construction. Many enterprises take interns as cheap labor, send them to the departments with manpower shortages and rarely arrange rotating internship opportunities for interns. The student interns cannot easily leave, although most experience offered is low-level operational practice and has nothing to do with management. This exploitation of students results in lost enthusiasm and interest in the travel industry before graduation.

\section{Lack of industry experience for teachers}

The teachers of tourism management majors in Chinese universities have a strong theoretical foundation, but less industry work experience. Most teachers have had contact with the industry, graduating from university and immediately returning to teach, lacking the actual industry experience. Teachers of "Tour Guide Practice" have never worked as tour guides and the teachers of "Hotel Management" have equally never worked in a hotel. This phenomenon is an important factor that it creates a further disconnect with industry demand.

\section{E. Simplistic evaluation}

The students' academic performance evaluation for most universities is limited to an examination. It is summarized by students as "taking notes in class, reciting notes after class and answering questions from notes in the exam". The evaluation of the practice becomes a mere formality, students need only have the internship units stamp in their internship manual, all the contents including internship evaluation are filled by themselves or by the internship with a one-size-fits-all comments.

\section{REFORM STRATEGY FOR TOURISM MANAGEMENT EDUCATION} IN UNIVERSITIES

\section{A. Curriculum Adjustment}

First of all, the curriculum should emphasise the requirements of the industry and strengthen the basic theory in the teaching content. The foundation of the tourism management major should be rooted in the fertile soil of the business management discipline. The basic theories and methods of business management have been researched for many years and provide a clear foundation. New research should be incorporated regularly. Second, courses should be industry focused. The practicality required by tourism industry skills training is the foundation of survival in this major. The tourism management course construction at undergraduate level should concentrate on the management level skills required by the tourism industry. Third, the curriculum should reflect the characteristics of "wide scope, deep foundation" in tourism management majors. Reference should be made to successful models of course design in other countries such as the United States and Japan, where the curriculum system consists of general education courses (public basic courses and cultural dialectics courses, accounting for $25 \%$ of the total credits), basic courses and specialized courses (accounting for $55 \%$ of the total credits), elective courses (accounting for $20 \%$ of the total credits). Presenting the curriculum in module structure and enhancing the flexibility of professional learning is favorable for the formation of adaptability and creativity.

\section{B. Reform teaching methods, including increased use of case studies}

- The experience of international tourism management institutions can be used for reference for improving teaching methodology. Firstly, build first-class electronic devices for use in classroom teaching, allowing multimedia teaching. This enables teachers to expand lecture information, enhance student interest, reduce lecture times and improve the teaching results. Secondly, build university practice bases, for example, the Hilton Hotel management school has about 10000 square meters of conference center, 2 full-time service restaurants, 1 cocktail hall, 3 libraries, 1 lab, 1 assessment center, 1 cooking demonstration classroom, all these bases provide students with good practice condition and the opportunity to exercise. Thirdly, set up scientific research institutions to research the current situation of the industry, its problems and development trends, providing the basis for the industry development and the update of teaching contents. Students can be encouraged to participate in the research developing their scientific research ability and giving real-life experience.

- Strengthen case study education. At the beginning of the 20th century Harvard University introduced the use of the case study to provide students with real situations to analyse and research, enabling them to understand 
actual issues and work to find solutions. The success of case study education depends on the interaction of teachers and students, being very "student centered". In tourism management education it uses hotel management related cases, simple but realistic, to enhance students' understanding, knowledge and problem solving skills. The teaching materials are specific events actually occurring regularly in the hotel industry. During the case study teaching process, teachers and students discuss together the enterprise behavior and decision and then put forward solutions. Teachers should communicate with students as required, capture the interesting ideas or insights of the students, and help students to summarise, deduce solutions, refining those solutions and present them. This participative method of case study education helps to cultivate students' independent thinking, independent analysis and the ability to solve practical problems.

\section{Strengthen practice teaching}

As Tourism management is an applied major, strengthening practice teaching is the necessary way of improving teaching quality.

- Adjust the teaching plan to ensure enough practice hours. In most foreign tourism colleges, the proportion of practice teaching is almost half of the whole teaching plan. We should draw lessons from foreign experience and improve the practice course from the original "auxiliary courses" to the "professional compulsory examination class", and set up corresponding credits and hours. In the teaching plan, we should clearly put forward the goal of practice teaching and practical implementation of the measures, which must be followed in the teaching process.

- Increase the building of laboratories. Tourism comprehensive laboratories are the various campus training rooms, and would work in conjunction with the theoretical course teaching. They provide students with good simulation of a professional atmosphere and a virtual practice environment. Many foreign tourism colleges have these labs to help complete the On-site teaching. The traditional tourism teaching mode can be modernised by building labs.

- Build a stable practice base. The base can provide students with stable internship places where they can make direct contact with tourism enterprises. The contract with these enterprises should ensure that the enterprise give students rotating internship opportunities including management work, and the full range of skills and management training. On the other hand, the enterprise needs to provide feedback to the school, enabling the school to adjust courses to run according to the changing requirements of the industry changes. This creates both a practice base stable and improves students' practice ability, and expands the influence of tourism schools in the industry.

\section{Develop students' scientific research capability}

As part of the improved teaching methodology, students should be required to study the problems of tourism through independent research and course work, and develop the ability to apply knowledge and analytical, deductive and evaluative skills. Teachers should encourage students to put forward new insights different from books and teachers' views and develop creativity and critical thinking skills. For example, foreign teachers often assign project in the class for students to study after class to foster students' autonomous learning ability, using the class only to provide basic knowledge and training, and students must research, work and practice outside the classroom.

Courses should be developed with the idea of using the graduation thesis writing process, as a real-life investigation and case study, not by way of reference. Copying case studies or other work would be forbidden and the graduation thesis is used as a demonstration of students' research ability.

The teacher should list students as member of the group when allocating subjects, make clear and specific requirements and guide their scientific research methodology, developing an interest in research and establishing the importance and necessity of scientific research.

\section{E. Increase teachers' industry experience}

- The university should give teachers more time to interact with the tourism industry and encourage them to cooperate with research or support. This cooperative approach can solve two problems: First, teachers' own experience is expanded which helps to update the teaching contents; second, is to use enterprise planning and operation experiences into teaching cases. By analyzing both success and failure, students will develop greater analytical abilities. Success stories exist in all kinds of tourism enterprises, and have both theoretical knowledge, and also rich actual experience. Teachers should take the initiative to interact with them, their enterprise planning operations and management experience can be translated into the specific cases and enrich the teaching.

- Invite the enterprise senior managers as visiting professors who can discuss new developments and new issues in the industry with the class. In this way, the full-time teachers and students can develop an understanding of the development of the tourism industry.

- Reform the requirements for the teachers' qualifications, to include a solid theoretical foundation, rich teaching experience and strong practical experience in the industry and urge teachers to improve themselves to adapt to the job requirements.

\section{F. Rebuild evaluation}

The Structure Results System would be appropriate for use in the tourism theory examination, as it includes knowledge and ability. In addition to the closed-book exam, course thesis, 
case analysis, and practice content should be important evaluation methods to reflect the students' overall ability.

An information feedback evaluation loop should be included for evaluating the practical training, with the training teachers or the internship units providing appropriate evaluation of the students' knowledge and ability based on the requirements of the work during the internship process, professional attitude, relationship with colleagues, the ability of to deal independently with problems, and looking for creativity and innovation. These elements together would create the final evaluation.

Students should be encouraged to master a foreign language, reaching a high set written/reading/comprehension standard, but also require them to achieve high level in the aspect of speaking and listening, and bring these into the routine assessment index.
For the evaluation of the teachers, a factor in addition to the graduate employment should include the encouragement of the students' individual development. By improving both student and teacher evaluations universities can increase career advancement opportunities t team spirit and leadership skills for both parties, and gain respect and recognition of the courses in the tourism industry.

\section{REFERENCES}

[1] Cao Guoxin, A review of researchers on the curriculum, teaching materials and method of tourism practice teaching, Tourism science, vol. 23, pp. 67-73, 2009.

[2] Wang Wenjun, A comparative study on tourism management undergraduate education between China and the United States, Tourism tribune, vol. 10, pp. 31-36, 2004.

[3] Han Binna, Lv Pinjing, A comparison of the practice teaching of the major of tourism studies in tertiary education between china and foreign countries, Human geography, vol. 25, pp. 154-157, 2010. 